\title{
Integration of metal hydride devices with polymer electrolyte fuel cells and electrolyzers for stationary applications
}

\author{
Dmitry Blinov ${ }^{1,2, *}$, Vasily Borzenko ${ }^{1}$, Aliya Glagoleva ${ }^{1,3}$ and Alexey Kazakov ${ }^{1}$ \\ ${ }^{1}$ Joint institute for high temperatures RAS, Krasnokazarmennaya str. 17a, Moscow, Russia \\ ${ }^{2}$ National Research University "Moscow Power Engineering Institute" Krasnokazarmennaya str. 14, Moscow, Russia \\ ${ }^{3}$ Skolkovo Institute of Science and Technology (Skoltech), Bolshoy blvd. 30, bld. 1, Moscow, Russia
}

\begin{abstract}
This paper presents the experimental results of the system integration of a fuel cell (FC), an electrolyzer and a metal hydride hydrogen storage and purification system. A pilot scale experimental power installation $\mathrm{H}_{2}$ Smart with an electric power of $1 \mathrm{~kW}$ is developed, and the results of its operation in different regimes are presented. The problems of hydrogen desorption for the supply of FC and hydrogen sorption from the electrolyzer at the start are shown. Possible solutions of this problem are proposed.
\end{abstract}

\section{Introduction}

According to the Energy Strategy of the Russian Federation-2030, the total capacity of renewable energy sources by 2030 should reach up to $6.1-14.3 \mathrm{GW}$ [1]. The involvement of renewable energy sources such as geothermal, solar, wind energy, bioenergy, etc. into the energy grid will help balance energy demand and reduce the environmental impact of energy producing companies. This will require development of efficient systems for energy storage produced by renewable energy sources in the daily, weekly and long-term seasonal schedules. Hydrogen is an environmentally friendly secondary energy carrier. Energy storage in hydrogen is a promising solution for autonomous and distributed power plants based on renewable sources. Moreover, hydrogen energy storage systems can be used together with conventional power plants such as nuclear, thermal power, etc. to store excess of energy and cover peak loads in power grids [2-5].

Russian Federation has large areas, which are not connected to Unified Energy System: 70\% of the Russia's territory, population about 20 million and $15 \%$ of main assets [6]. The potential of cost-effective renewable energy projects is expected as high as $1 \mathrm{GW}$ for isolated energy systems in remote areas. The main objectives are a modernization of power generation plants for use of local renewable energy sources, a significant reduction of diesel fuel supply, and a sustainable infrastructure growth of remote territories.

Currently small power plants based on renewables are highly demanded by the market for energy and heat supply of autonomous consumers. It is a matter of great importance to overcome the problem of energy supply irregularity from renewables and associated drawback of long-term energy storage in weekly and seasonal cycles for the widespread renewable energy power plants application. Hydrogen energy technologies could be a promising solution.

Fuel cell-based power plants are considered as promising energy generation units in low kilowatt power range due to their high efficiency. These power plants with an installed capacity of $1-20 \mathrm{~kW}$ can be widely used for autonomous and uninterruptible power supply for different consumers: telecommunications, data centers, medical institutions, etc. The power plant installation close to the consumer requires increased safety, reliability and environmental friendliness. Only high purity hydrogen can be used as a fuel for such power plants. Nowadays low temperature fuel cells (PEM or alkaline) with efficiency $55 \%$ and water electrolyzers at elevated pressures with efficiency more than $75 \%$ and energy consumption not exceeding $4.2-4.4 \mathrm{kWh} / \mathrm{Nm}^{3}$ are available in the market [4]. For «electrolyzer - fuel cell» system energy recuperation can reach $40 \%$, which is acceptable for renewable energy power plants. However, development and integration of energy efficient hydrogen storage system is still a technical barrier in construction of such renewable based power plants.

Metal hydride systems are promising as hydrogen storage devices for stationary power plants based on renewables. Metal hydrides are able to reversibly absorb hydrogen and store it in solid state phase, which provides higher safety at operation [7, 8]. Usually, absorption of hydrogen by metal hydrides is exothermic and accompanied by heat release, and hydrogen desorption is endothermic, which needs heat supply $[9,10]$. This effect allows to use low grade heat of fuel cell for hydrogen release from metal hydride bed. Main drawback of development effective metal hydride devices is low effective thermal conductivity of metal hydride powder beds (about $1 \mathrm{~W} / \mathrm{m} \cdot \mathrm{K}$ ), which are fine dispersed powder with a mean size $1-10 \mu \mathrm{m}$. Effective thermal conductivity is strongly depends on hydrogen pressure

D.V.Blinov.JIHTRAS@yandex.ru 
and concentration of absorbed hydrogen in the alloy particles [9]. In combination with a large heat effects of hydrogen absorption/desorption reaction the absence of sufficient heat removal/supply from/to the metal hydride bed can significantly reduce hydrogen absorption/desorption kinetics during metal hydride device operation [11]. Another obstacle is related to the presence of non-absorbable impurity gases in hydrogen feeding gas, which are able to lower process kinetics due to gas blanketing effect $[2,12,13]$.

Selective hydrogen absorption by metal hydrides can be used for purification of technical grade hydrogen directly in a fuel supply system, thereby reducing total fuel costs. Depending on the contamination level of hydrogen and purification regime a fraction of impurities in hydrogen released from metal hydride will not exceed $10^{-4}-10^{-2}$ vol.\%. High safety, reliability and efficiency of metal hydride hydrogen storage systems make them perspective for autonomous power plants based on low temperature fuel cells.

Recently, air-cooled fuel cells have reached a high efficiency and widespread implementation level, actively displacing liquid-cooled fuel cells from the market in the 1-10 kW power range, therefore the integration of such fuel cells with metal hydride hydrogen storage systems is actual.

\section{Selection of hydrogen storage alloy}

The performance characteristics of metal hydride systems as a part of integrated power plants must meet the requirements both low-temperature fuel cells (delivery pressure, hydrogen purity) and electrolyzer (inlet pressure). Selection of an appropriate alloy composition with the necessary absorption/desorption pressures in the temperature range of $0-100^{\circ} \mathrm{C}$ allows to meet the requirements for hydrogen storage and purification, as well as hydrogen compression.

Intermetallic compounds are promising materials for hydrogen storage and purification. They can be represented by the general formula $\mathrm{A}_{m} \mathrm{~B}_{n} \mathrm{H}_{\mathrm{x}}$, where $\mathrm{A}$ is a metal that forms a stable binary hydride, metal $\mathrm{B}$ does not react with hydrogen under normal conditions (usually a transition metal, for example, $\mathrm{Fe}, \mathrm{Co}, \mathrm{Ni}, \mathrm{V}, \mathrm{Mn}, \mathrm{Cr}$, etc.). Commonly, $\mathrm{AB}_{5}$ (A - rare-earth metals, $\mathrm{Ca}$ ), $\mathrm{AB}_{2}$ and $\mathrm{AB}$ (A - elements of the subgroup of titanium), $\mathrm{A}_{2} \mathrm{~B}$ (A usually $\mathrm{Mg}$ ) type alloys are of the most practical importance. Operating pressure in hydrogen storage systems can vary from 0.1 to $\sim 10$ bar as temperatures vary from 20 to $80-90{ }^{\circ} \mathrm{C}$. This allows you to ensure that the processes of absorption and evolution of hydrogen due to the coolant resources in the fuel cell or electrolyzer. Thereby, waste heat resources from fuel cell or electrolyzer can be used for metal hydride system operation.

The preparation of intermetallic compounds is conducted in an arc melting furnace Cianflone 2701 with tungsten electrode in a water-cooled copper crucible under argon atmosphere [14]. The alloy with composition $\mathrm{La}_{0.9} \mathrm{Ce}_{0.1} \mathrm{Ni}_{5}$ is chosen as metal hydride material with appropriate hydrogen capacity, equilibrium pressures in required temperature range. A measurement of hydrogen sorption properties is conducted by Sievert's technique (Fig.1.) [15].

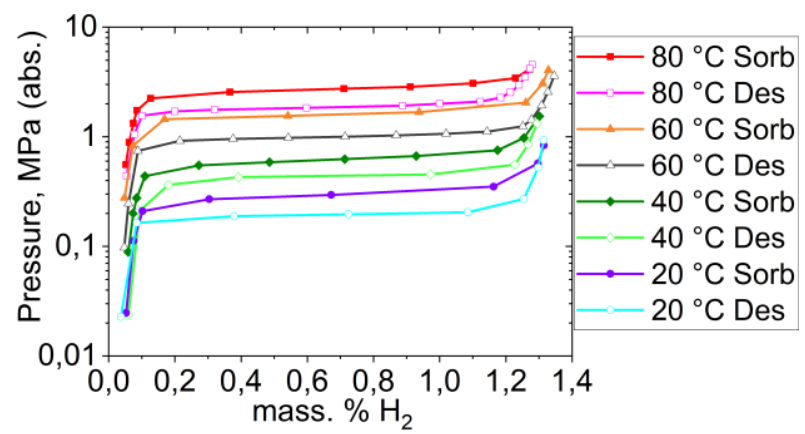

Fig.1. Hydrogen sorption/desorption «pressure-concentrationtemperature» diagram for $\mathrm{La}_{0.9} \mathrm{Ce}_{0.1} \mathrm{Ni}_{5}$ alloy [15].

Operation hydrogen pressure for polymer electrolyte membrane (PEM) fuel cell Hoppecke E-1100 supply should be in a range from 0.155 to $0.183 \mathrm{MPa}$. The selected alloy provides required pressure at room temperature. Hydrogen desorption pressure at $20{ }^{\circ} \mathrm{C}$ is around $0.2 \mathrm{MPa}$. On the other side, electrolyzer produces hydrogen at production rate of $100 \mathrm{Nl} / \mathrm{h}$ and hydrogen pressure $0.3 \mathrm{MPa}$. As seen from Fig.1., the outlet hydrogen pressure is sufficient to supply metal hydride hydrogen storage system [11].

\section{Experimental power plant H2Smart}

The H2Smart experimental power plant (Fig. 2) includes a hydrogen production subsystem (H2Box-100), a lowpressure hydrogen storage subsystem (the RSP-1 reactor), an electric power generation subsystem (Ltd. «Hoppecke»), as well as an automated control system. The main characteristics of each subsystem are presented in Table 1.

The system is mounted as a separate module and placed in a standard 19-inch rack. The dimensions and weight of the module allow its placement in rooms with a doorway width of at least $800 \mathrm{~mm}$ and transportation on a horizontal surface by forces of one person.

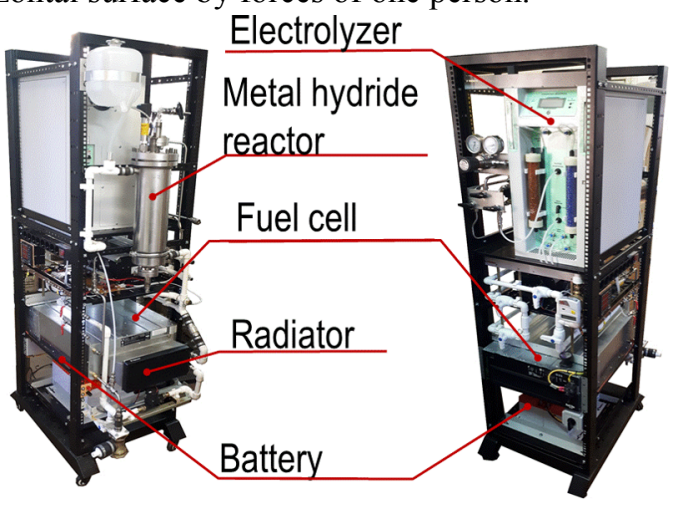

Fig. 2. General view of H2Smart experimental power plant.

Metal hydride reactor RSP-1 (Fig.3) is used as a lowpressure hydrogen storage subsystem and provides long term storage of hydrogen produced by electrolyze subsystem as well as from external hydrogen sources. 


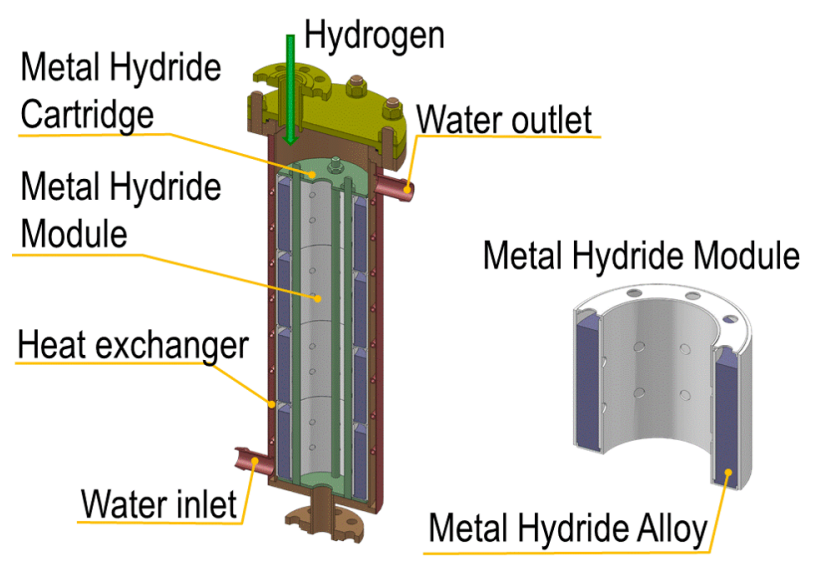

Fig. 3. Metal hydride hydrogen storage reactor RSP-1

Metal hydride reactor RSP-1 consists of four modules with metal hydride powder joint into one cartridge, water heat exchanger and installed fittings and connectors for pressure and temperature sensors.

Intermetallic compound $\mathrm{La}_{0 .} \mathrm{Ce}_{0.1} \mathrm{Ni}_{5}$ is filled as powder in each module approximately $70-80 \%$ of its volume. Free space is necessary to compensate volume change of metal hydride powder during hydrogen sorption and desorption. The use of separate metal hydride modules allows to avoid metal hydride powder compaction and particle agglomeration. In addition, highly conductive metal walls are similar to fins, improving heat transfer to the powder bed. The modular design of reactor facilitates its maintenance.

Table 1. The main technical characteristics of RSP-1 metal hydride reactor, electrolyzer H2Box, PEM fuel cell Hoppecke E-1100.

\begin{tabular}{|l|l|}
\hline \multicolumn{2}{|c|}{ Metal hydride reactor RSP-1 } \\
\hline Inlet pressure $p_{0}, \mathrm{MPa}$ & 0.3 \\
\hline Temperature of coolant fluid $T_{\mathrm{f}},{ }^{\circ} \mathrm{C}$ & 15 \\
\hline $\begin{array}{l}\text { Heat transfer coefficient from reactor's } \\
\text { walls to coolant fluid } \alpha_{\mathrm{f}}, \mathrm{W} / \mathrm{m}^{2} \cdot \mathrm{K}\end{array}$ & 2000 \\
\hline Length of the reactor $L, \mathrm{~mm}$ & 1100 \\
\hline $\begin{array}{l}\text { Mean size of metal hydride particles } d_{\mathrm{p}}, \\
\mu \mathrm{m}\end{array}$ & 10 \\
\hline Porosity of metal hydride bed $\varepsilon$ & 0.5 \\
\hline Alloy composition & $\mathrm{La}_{0.9} \mathrm{Ce}_{0.1} \mathrm{Ni}_{5}$ \\
\hline Alloy mass, $\mathrm{g}$ & 5000.55 \\
\hline \multicolumn{2}{|c|}{ Electrolyzer H2Box-100 } \\
\hline Hydrogen purity, \%vol. & 99.99 \\
\hline $\begin{array}{l}\text { Nominal hydrogen production rate, } \\
\text { Nl/h }\end{array}$ & 100 \\
\hline Outlet hydrogen pressure, $\mathrm{MPa}$ & $0.15-0.3$ \\
\hline Nominal power consumption, VA & $<450$ \\
\hline \multicolumn{2}{|c|}{ PEM fuel cell Hoppecke E-1100 } \\
\hline Maximum power, W & 1000 \\
\hline Maximum current, A & 23 \\
\hline Nominal voltage, $\mathrm{V}$ & $48(\mathrm{DC})$ \\
\hline Hydrogen cosumption rate, Nl/h & $\mathrm{Up}$ to 14 \\
\hline Hydrogen purity, \%vol & 99.95 \\
\hline Inlet hydrogen pressure, MPa & $0.12-0.18$ \\
\hline Cooling fluid & Air \\
\hline
\end{tabular}

Electrolyzer H2box-100 («Gidrogenius Ltd.») is used as hydrogen production subsystem. The main component of H2Box-100 is an electrolyzer with solid polymer electrolyte with a high proven resource (more than 20000h). It has fully electronic control, ensures electricity conversion no less than $96.5 \%$. The electrolysis cell consists of 18 electrochemical cells.

The electric power generation subsystem consists of PEM fuel cell Hoppecke E-1100, DC/AC invertor and battery pack.

\section{The operation principle of experimental power plant}

The experimental power plant utilizes electrical energy from reneawble sources or simulated renewable electical energy. The hydrogen produced by electrolysis is processed through a hydrogen dehumidifier that is integrated to the electrolyzer due to the requirements of low humidity hydrogen supply for metal hydride system. Dehumidified hydrogen enters inside the reactor, where sorption process starts. Since hydrogen absorption is exothermic reaction thus cold water supplied to the reactor either through an external input or from the radiator providing heat removal from the reaction bed. Hydrogen is stored in the reactor until the demand load exceeds the electricity production rate from the renewable sources of energy or the simulation of such production. When demand occurs, the FC is started by integrated battery pack and hydrogen is released from the reactor by desorption process with additional heat supplied. After the $\mathrm{FC}$ has reached nominal operational conditions $\left(60^{\circ} \mathrm{C}-\right.$ $80^{\circ} \mathrm{C}$ inside the stack), the radiator starts to collect waste heat from the cooling fans of the FC and sends warmed water to the reactor for further desorption process of hydrogen. The H2Smart output is a $220 \mathrm{~V}$ outlet through an inverter. An automated system collects different sets of data and responds to the user changes made in LabView interface using NI-PXI integrated to a personal computer.

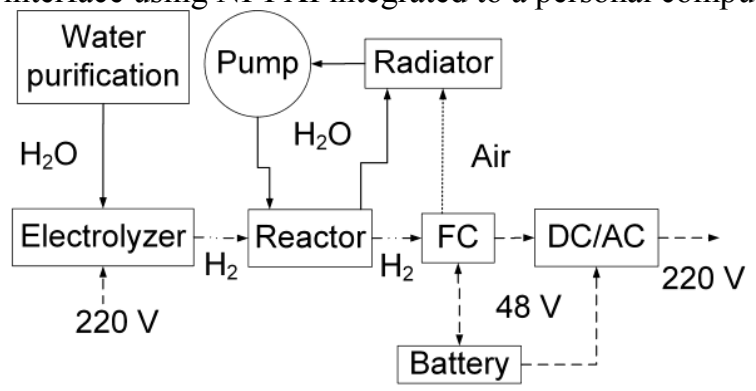

Fig. 4. The scheme of the H2Smart experimental setup

\section{Experimental investigations of the system integration of a fuel cell, electrolyzer and metal hydride reactor}

The integrated experimental power plant is tested in different operation regimes. Charging of the metal hydride reactor from the electrolyzer is carried out in "passive" and "active" cooling regimes. Second step is discharging the stored hydrogen to the fuel cell. 
The regime of "passive" cooling during metal hydride reactor charging is conducte by a water circulation in the internal circuit of the power plant. Water consumption is $0.4 \mathrm{~m}^{3} / \mathrm{h}$. The initial temperature of water is $22{ }^{\circ} \mathrm{C}$. Additional cooling of water or mixing from the external source is not applied. The collected data are presented in Figs. 5 and 6.

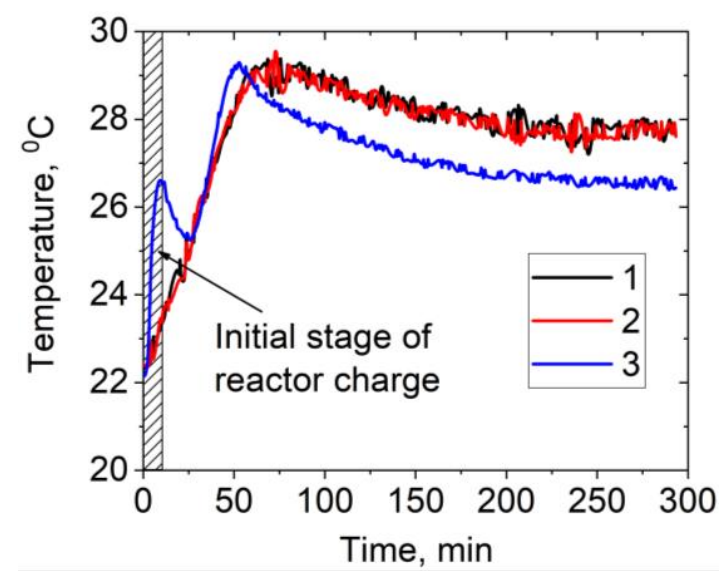

Fig. 5. "Passive" cooling: coolant temperature distribution in RSP-1 reactor: 1 - at inlet of the reactor; 2 - at outlet of the reactor; 3 - inside the reactor.

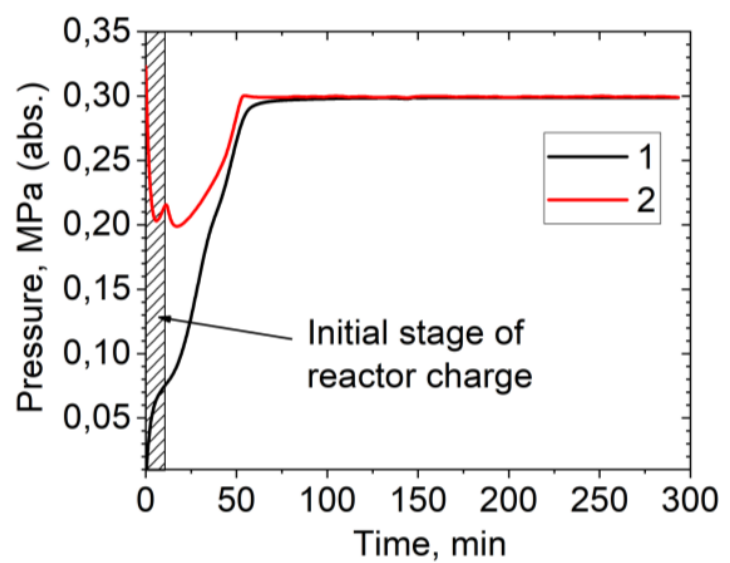

Fig. 6. "Passive" cooling: hydrogen pressure distribution: 1 inside the reactor; 2 - pressure supplied from electrolyzer.

At the initial stage, the temperature of metal hydride bed significantly rises (Fig.5). In the case of "passive" cooling, insufficient heat transfer from the metal hydride bed leads to temperature increase up to $29{ }^{\circ} \mathrm{C}$. Thus temperature inside the bed reaches new equilibrium, then hydrogen absorption pressure also increases. In turn, it leads to decrease a pressure difference between inlet and equilibrium pressures, which is a main driving force for absorption (Fig. 6). Thus, metal hydride reactor charging is strongly inhibited by heat and mass transfer crisis [11]. The RSP-1 reactor is not able to absorb hydrogen at a constant hydrogen flow rate (Fig.7). Resulting cumulative volume of absorbed hydrogen is aproximately $90 \mathrm{Nl}$, which is just $15 \%$ of nominal capacity of RSP-1 reactor (Fig.7). As a result, "passive" cooling regime does not meet the requirements for necessary heat transfer from metal hydride bed during charging of RSP-1 reactor.

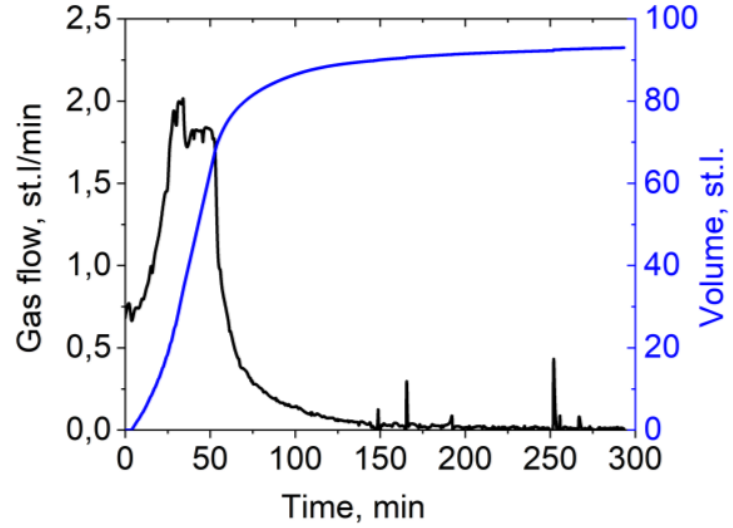

Fig. 7. "Passive" cooling: black line - hydrogen flow rate at RSP-1 charging, blue line - cumulative volume of absorbed hydrogen in RSP-1.

The charging of RSP-1 reactor in case of "active" cooling regime is carried out by cold water supply to the reactor's heat exchange circuit. Cold water temperature is $5.5^{\circ} \mathrm{C}$ and its flow rate is $0.4 \mathrm{~m}^{3} / \mathrm{h}$ (Fig.8).

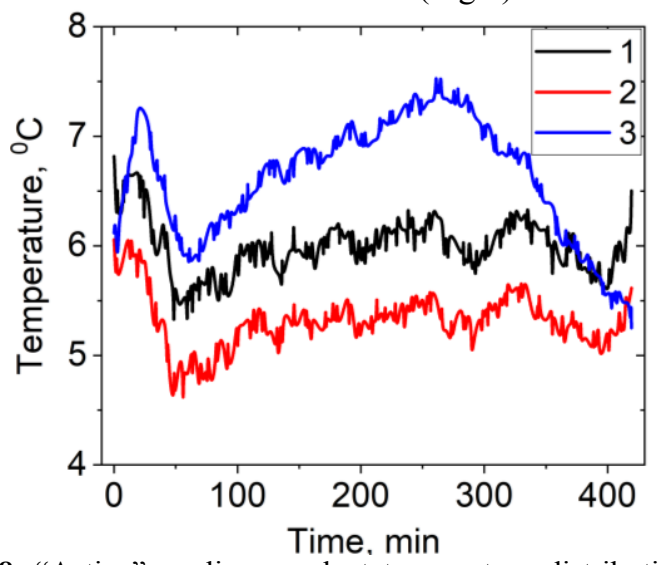

Fig. 8. "Active" cooling: coolant temperature distribution in RSP-1 reactor: 1 - at inlet of the reactor; 2 - at outlet of the reactor; 3 - inside the reactor.

The temperature profiles are fairly flat without any rapid temperature increase, which indicates good heat removal from reaction bed. Equilibrium pressure inside the reactor increases much slower and does not influence on sorption kinetics until almost full charge of reactor (Fig.9).

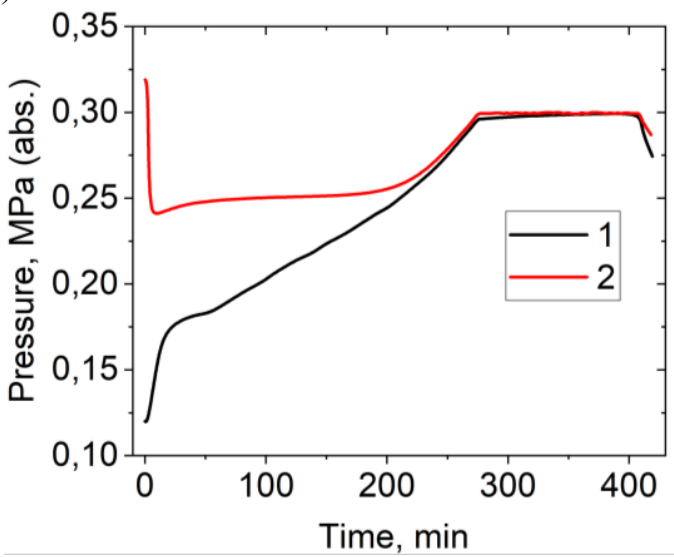

Fig. 9. "Active" cooling: hydrogen pressure distribution: 1 - inside the reactor; 2 - pressure supplied from electrolyzer. 
Effective cooling of metal hydride bed makes possible to charge RSP-1 at constant hydrogen flow rate during most of the experiment (Fig.10).

Main changes occur at the end of charging process. During first 270 minutes metal hydride bed absorbs 500 $\mathrm{N}^{\mathrm{H}} \mathrm{H}_{2}$ which is $83 \%$ of hydrogen capacity at flow rate 1.8 $\mathrm{N} \mathrm{H}_{2} /$ min. To the moment metal hydride bed temperature slightly increases up to $7.5^{\circ} \mathrm{C}$. And then both temperature and hydrogen flow rate drastically decreases caused by saturation of metal hydride bed. During following 130 minutes RSP-1 absorbs just a small amount of hydrogen, approximately $90 \mathrm{Nl}$ (Fig.10).

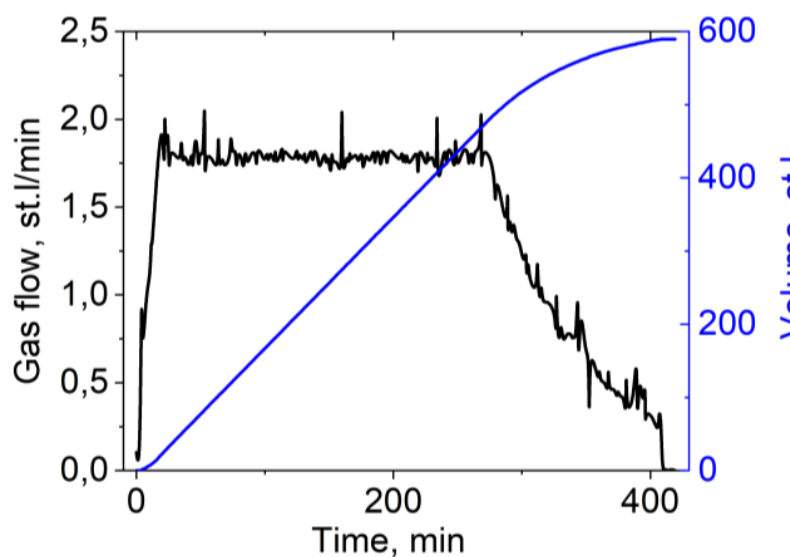

Fig. 10. "Active" cooling: black line - hydrogen flow rate at RSP-1 charging, blue line - cumulative volume of absorbed hydrogen in RSP-1.

The discharge of the RSP-1 reactor is provided waste heat air exhaust from fuel cell operation. The current study continues the investigations started in [16, 17]. Series of investigations are conducted to define operational characteristics of fuel cell coupled with metal hydride reactor as hydrogen source and to detect heat transfer limitations in metal hydride bed during operation.

At the start of coupled operation of metal hydride reactor and fuel cell, significant pressure drop in the metal hydride reactor occurs (Fig. 11). Fuel cell cannot supply enough heat during first minutes of operation and lack of heat in the reactor causes pressure drop. Due to hydrogen sorption properties of selected alloy, supply pressure is enough even at these unfavorable conditions (Fig. 12). Without heat supply to metal hydride bed the pressure drop can be more significant and equilibrium hydrogen pressure will be lower than required pressure, that will lead to shutdown of fuel cell. Heat transfer in metal hydride bed is a limiting step for start of fuel cell. It should be taken into account at integration of metal hydride storage systems with fuel cell.

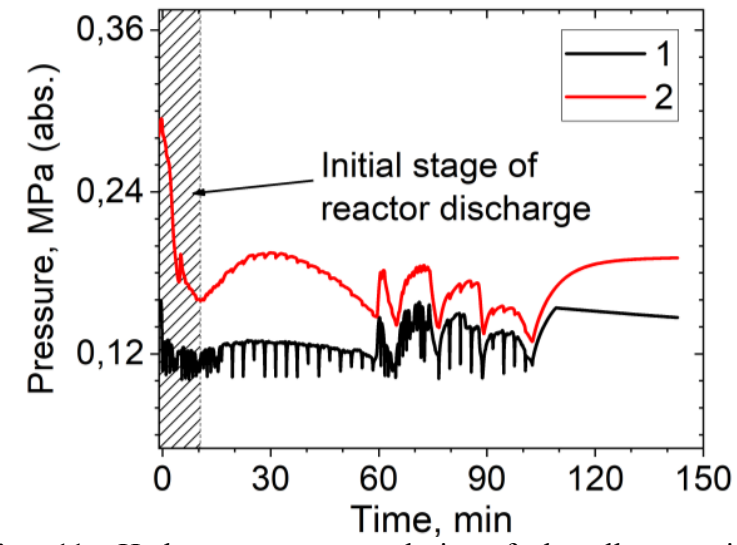

Fig. 11. Hydrogen pressure during fuel cell operation: 1 - equilibrium pressure inside metal hydride reactor; 2 - pressure at the inlet valve to fuel cell.

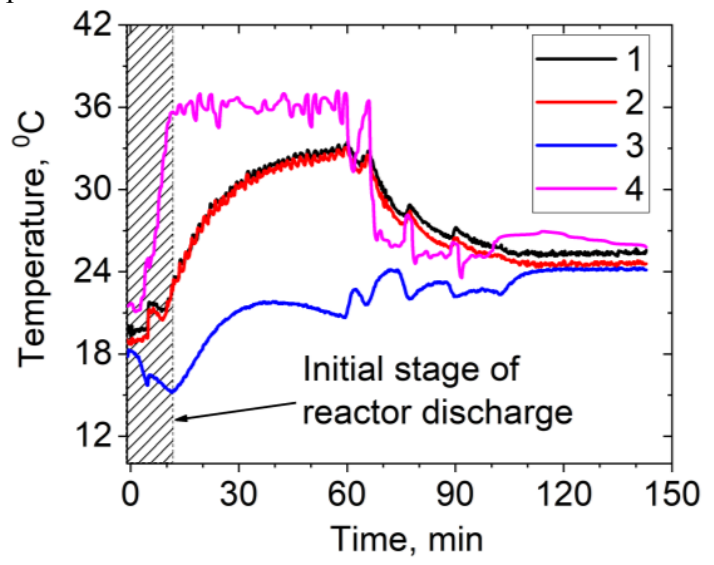

Fig. 12. Temperature profiles during fuel cell operation: 1 - water temperature at inlet of the reactor; 2 - water temperature at outlet of the reactor; 3 - temperature inside the reactor; $4-$ air temperature at outlet of the fuel cell.

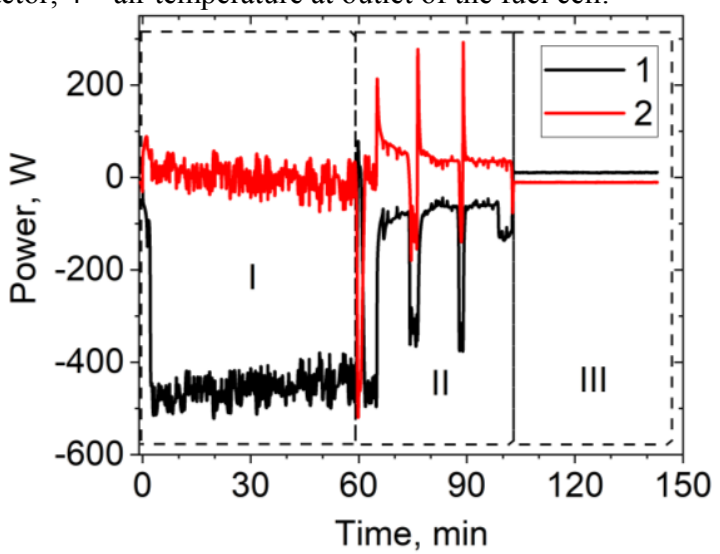

Fig. 13. PEM fuel cell operation supplied by metal hydride reactor: I - stable operation; II - unstable operation; III - fuel cell shut down.

While fuel cell produces more heat, metal hydride bed is heated to appropriate level $30-33{ }^{\circ} \mathrm{C}$ and release hydrogen during one hour to supply fuel cell at load 500 W (area I Fig. 13). That is normal operation of fuel cell supplied by hydrogen from metal hydride reactor. At current heat flow from fuel cell, hydrogen equilibrium pressure in metal hydride reactor decreases after thirty minutes of operation. The main reason is plateau slope, which characteristic for real intermetallic compounds. The plateau slope is a small change of equilibrium 
pressure in the two-phase region of PCT diagram, which defines reversible capacity of metal hydride alloy. More heat flow is necessary to obtain required pressure for fuel cell operation. After 60 minutes metal hydride reactor - fuel cell system operates in unstable regime (area II Fig 13). The fuel cell periodically shuts down because of insufficient hydrogen pressure from metal hydride reactor. However, additional heating of metal hydride reactor restarts the fuel cell operation until next pressure drop occurs. To time point of 100 minutes almost all hydrogen from metal hydride reactor is released, and fuel cell is turned off.

Main obstacle for integration of metal hydride storage system and fuel cell is a problem of "cold" start. If fuel cell starts at low temperatures or at half charged metal hydride reactor equilibrium hydrogen can be inadequate for fuel cell operation. To overcome this drawback several techniques can be applied:

1. Additional cooling/heating for charge/discharge of the reactor from external sources: solar collectors, heat pump, Peltier elements, hot or cold tap water, refrigeration cycle.

2. The use of high pressure electrolyzer to reach higher hydrogen pressure in a free volume of metal hydride reactor. At discharge stage free volume of reactor is an additional buffer to fuel cell supply. At charge stage higher inlet hydrogen pressure from electrolyzer will increase pressure difference and improve sorption process.

3. The use of additional buffer volume before inlet valve of fuel cell.

4. Optimization of heat and mass transfer by improving reactor design and system design as a whole. The current reactor has a thick layer of metal hydride powder which has low effective thermal conductivity. The use of thin layer of metal hydride powder in the reactor, addition of high thermal conductive materials such as copper or aluminum foam, optimization of heat losses by thermal insulation of the reactor can significantly improve heat and mass transfer characteristics of the developed energy system.

5. Proper selection of intermetallic compound with required PCT properties according to real operation conditions in the climatic zone, where power plant will work. The metal hydride system must provide required hydrogen pressure even in case of low temperatures in order to eliminate pressure drop during start of hydrogen desorption.

\section{Conclusions}

A system integration of metal hydride hydrogen storage reactor with electrolyzer and PEM fuel cell is presented. Experimental power plant with nominal output power up to $1 \mathrm{~kW}$ consisting of PEM electrolyzer, metal hydride reactor and PEM fuel cell is experimentally investigated in different conditions.

Integration of metal hydride reactor with electrolyzer to store produced hydrogen is performed in two conditions of "passive" and "active" cooling. At "passive" cooling metal hydride reactor filled with $\mathrm{La}_{0.9} \mathrm{Ce}_{0.1} \mathrm{Ni}_{5}$ mass of $5 \mathrm{~kg}$ is not sufficiently cooled due to heat transfer limitations and is able to sorb just $90 \mathrm{Nl} \mathrm{H}$. At "active" cooling no heat transfer limitations occur, so metal hydride reactor is almost fully charged during the same period.

The discharge of metal hydride reactor to supply fuel cell is conducted by waste heat from fuel cell. Except first minutes after fuel cell start, when hydrogen pressure drop occurs because of insufficient heat supply, metal hydride reactor provides fuel cell operation during one hour with power load $500 \mathrm{~W}$ using heat flow from fuel cell. Several solutions to overcome the problem of "cold" start of fuel cell are proposed such as use of additional cooling/heating or high-pressure buffer, optimization of heat and mass transfer by reactor design, addition high thermal conductive materials, proper selection of alloy composition to meet the requirements for real operation conditions.

\section{References}

1. Rossijskaya Federaciya. Energeticheskaya strategiya Rossii na period do 2030 goda. 2009.

2. Malyshenko S.P., Borzenko V.I., Dunikov D.O., Nazarova O.V. Metallogidridnye tekhnologii vodorodnogo akkumulirovaniya energii dlya avtonomnyh sistem energoobespecheniya na osnove vozobnovlyaemyh istochnikov energii, Teploenergetika 2012(6): p. 50-60.

3. Malyshenko S.P. Vodorod kak akkumulyator energii v elektroenergetike, Rossijskij himicheskij zhurnal. 2005. XLI: p. 112-120.

4. Hydrogen and Fuel Cells: Fundamentals, Technologies and Applications. 2010, Weinheim, Germany: WILEY-VCH Verlag GmbH. 877.

5. Zoulias, E.I. and N. Lymberopoulos, Hydrogen-based autonomous power systems: techno-economic analysis of the integration of hydrogen in autonomous power systems. 2008: Springer.

6. Dunikov, D.O., Russia's view on development of novel and renewable energy sources, including hydrogen energy. International Journal of Hydrogen Energy, 2015. 40(4): p. 2062-2063.

7. Tarasov B.P., Burnasheva V.V., Lotockij M.V., YArtys' V.A. Metody hraneniya vodoroda $i$ vozmozhnosti ispol'zovaniya metallogidridov, Al'ternativnaya energetika i ekologiya 2005. 12: p. 14-37.

8. Sandrock, G., A panoramic overview of hydrogen storage alloys from a gas reaction point of view. Journal of Alloys and Compounds, 1999. 293-295: p. 877-888.

9. Sun, D.-W. and S.-J. Deng, A theoretical model predicting the effective thermal conductivity in powdered metal hydride beds. International Journal of Hydrogen Energy, 1990. 15(5): p. 331-336.

10. Mordkovich, V.Z., et al., Comparative efficiency of using hydrides in industrial processes of hydrogen recovery and compression. International Journal of Hydrogen Energy, 1993. 18(10): p. 839-842.

11. Borzenko, V., D. Dunikov, and S. Malyshenko, Crisis phenomena in metal hydride hydrogen storage facilities. High Temperature, 2011. 49(2): p. 249-256. 
12. Blinov, D.V., et al., Experimental investigations of thermal processes in the flow-throw hydrogen purification reactor. Journal of Physics: Conference Series, 2018. 1128: p. 012120.

13. Dunikov, D., V. Borzenko, and S. Malyshenko, Influence of impurities on hydrogen absorption in a metal hydride reactor. International Journal of Hydrogen Energy, 2012. 37(18): p. 13843-13848.

14. Kazakov A.N., Dunikov D.O., Borzenko V.I Razrabotka metodiki izgotovleniya $i$ issledovaniya obrazcov intermetallicheskih soedinenij dlya sistem hraneniya i ochistki biovodoroda, Vestnik MEI 2014. 3: p. 16-20.

15. Borzenko, V.I., et al., Hydrogen sorption properties of metal hydride beds: Effect of internal stresses caused by reactor geometry. International Journal of Hydrogen Energy, 2019. 44(12): p. 6086-6092.

16. Khayrullina, A., D. Blinov, and V. Borzenko, Air heated metal hydride energy storage system design and experiments for microgrid applications. International Journal of Hydrogen Energy, 2019. 44(35): p. 1916819176.

17. Borzenko, V. and A. Eronin, The use of air as heating agent in hydrogen metal hydride storage coupled with PEM fuel cell. International Journal of Hydrogen Energy, 2016. 41(48): p. 23120-23124. 